\title{
DYING TO SAVE TAXES: EVIDENCE FROM ESTATE-TAX RETURNS ON THE DEATH ELASTICITY
}

\author{
Wojciech Kopczuk and Joel Slemrod*
}

\begin{abstract}
This paper examines data from U.S. federal tax returns to shed light on whether the timing of death is responsive to its tax consequences. We investigate the temporal pattern of deaths around the time of changes in the estate-tax system periods when living longer, or dying sooner, could significantly affect estate-tax liability. We find some evidence that there is a small death elasticity, although we cannot rule out that what we have uncovered is ex post doctoring of the reported date of death.
\end{abstract}

\section{Introduction}

$\mathrm{O}$ N January 15, 2000, The New York Times reported that in the first week of the new millennium local hospitals had recorded an astonishing $50.8 \%$ more deaths than in the last week of 1999.' The Times suggested that this phenomenon was due to infirm people willing themselves to stay alive long enough to witness the dawning of the new age. Apparently, the anticipation of momentous events can motivate people to live longer.

This evidence raises the intriguing question of whether the timing of death responds to economic factors. Could the timing of death be. to some extent, a rational decision? Economists presume that the timing of other important events, such as childbearing or marriage, may be so affectedwhy not dying as well?

In this paper we examine data from U.S. federal estatetax returns to shed light on this question. We investigate the temporal pattern of deaths around the time of changes in the estate-tax system-periods when living longer (or dying sooner) could significantly affect estate-tax liability. These periods provide ideal natural experiments enabling us to test for the presence and strength of this particular kind of behavioral response to taxes.

\section{A. Evidence on the Effect of Taxation on the Timing of Economic Decisions}

There is a vast literature, briefly summarized in Auerbach and Slemrod (1997), concerning the impact of taxation on economic decisions ranging from labor supply to business organization to exercise of stock options. Slemrod (1990) characterized the magnitude of behavioral response as fitting a hierarchy, at the top of which, with the largest degree

Received for publication February 14, 2001. Revision accepted for publication January 25, 2002.

* University of British Columbia and University of Michigan, respectively.

We are grateful to the Statistics of Income Division of the Internal Revenue Service for allowing access to confidential estate-tax return data under a data disclosure agreement. We especially thank Barty Johnson of SOI for patiently explaining the data structure and facilitating our analysis. Alex Fisher. Robert Greebel. and Cassie Stone provided assistance on the history of estate-tax provisions. David Lenter provided assistance with mortality data. We thank David D. Jones, David Joulfaian, Janet McCubbin. and Antonio Rangel for valuable comments.

'Hershey (2000). of responsiveness, lies the timing of transactions with respect to anticipated changes in the tax structure. ${ }^{2}$ The classic example, detailed in Burman, Clausing, and O'Hare (1994), is the increase in capital-gains realizations in 1986 in anticipation of increased taxation beginning the next year. Realizations increased from $\$ 167$ billion in 1985 to $\$ 322$ billion in 1986, only to fall back to $\$ 137$ billion in 1987 . Long-term capital-gains realizations of corporate stock in December of 1986 were nearly seven times their level in the same month of 1985 . Other examples of large timing responses include exercise of stock options (Goolsbee, 2000), charitable contributions (Burman and Randolph, 1994), and firms' shifting of taxable income through deferred income recognition and accelerated expense recognition (Scholes, Wilson, and Wolfson, 1992).

\section{B. Evidence on the Effect of Taxation on the Timing of "Noneconomic" Decisions}

There is also evidence that financial considerations affect the timing of decisions that are not generally thought of as being economic. For example, Sjoquist and Walker (1995) conclude from an analysis of Census data that the marriage penalty embedded in the U.S. income tax has a significant negative effect on the timing of marriages: as the penalty increases, fewer couples marry in the months of November and December relative to the number of marriages during the first few months of spring in the new year. Alm and Whittington (1995), using data from the Panel Study on Income Dynamics, also find that taxes have a significant effect on the probability of a couple delaying marriage from the last quarter of one year to the first quarter of the next year. They find no evidence, though, of taxes having an effect on speeding divorce to the current year to avoid a year's marriage penalty. Gelardi (1996) reports a significant drop in the percentage of marriages occurring in the last months of the tax year following tax-law amendments in Canada, as well as in England and Wales, designed to eliminate the tax benefit of marrying just prior to the tax year-end.

Dickert-Conlin and Chandra (1999) find that the timing of births is sensitive to tax incentives. Under the U.S. tax system, the tax benefits of having a child are (fully) realized only if the birth takes place before midnight, January 1 . Using a sample of children from the National Longitudinal

\footnotetext{
2 The second rung of the hierarchy includes accounting and renaming responses, such as the shift from Subchapter $C$ to Subchapter $S$ corporations after the Tax Reform Act of 1986 inverted the long-standing relationship of the top corporate and top individual tax rates. The third rung, the least responsive, comprises "real" decisions such as labor supply or saving.
} 
Survey of Youth, Dickert-Conlin and Chandra find that the probability that a child is born in the last week of December, rather than the tirst week of January, is positively correlated with tax benefits from so doing; they estimate that increasing the tax benefit by $\$ 500$ raises the probability of having a child in the last week of December by $26.9 \%$.

\section{The Timing of Death}

If birth, why not death? Of course, barring a future technological advance, any effect of tax policy on death could only be a timing response. There is certainly a large literature on how average longevity responds to changes in, for example, health care, but we know of no evidence about its high-frequency response to pecuniary incentives. In the introduction we referred to the millennium-end evidence that the timing of death is responsive to nonpecuniary incentives. There is a substantial body of evidence corroborating this phenomenon in other contexts. Phillips and King (1988) report that, among Jews, the number of deaths was lower than expected in the week before Passover and higher than expected in the week after; the pattern was most pronounced in years when the holiday fell on a weekend, when it is most likely to be celebrated by the largest number of people. Phillips and Smith (1990) find that mortality among Chinese dips by $35.1 \%$ in the week before the Harvest Moon festival and peaks by the same amount in the week after. Anson and Anson (1997) find a similar effect related to the timing of Ramadan for Moslems living in Israel, and note that the effect was larger for women than for men, reflecting their different roles in the celebration of the holy-day rites. Phillips and Feldman (1973) claim that the same phenomenon occurs around birthdays and presidential elections, although Schulz and Bazerman (1980) argue that this analysis does not withstand close scrutiny. The consensus of this literature is that death can be briefly postponed until after the occurrence of a significant occasion. ${ }^{3}$

\section{Implications for Bequest Motives}

A nonzero death elasticity is consistent with the notion of a bequest motive. Altruistic individuals should consider adjusting the timing of their death if by so doing it will benefit their heirs. There is, however, another possibility. Decisions about prolonging the life of a critically ill person (e.g., regarding whether to continue with life support) are often made not by the dying person but by others, including the potential heirs themselves. For this reason, observing a nonzero death elasticity would not definitively establish the presence of an altruistic bequest motive on the part of the decedent. Note, however, that a parent anticipating the possibility of self-serving behavior by potential heirs might at an earlier time alter his or her behavior, perhaps by

\footnotetext{
${ }^{3}$ There is also a literature on the pattern of suicides around major public holidays, but the contentious findings on this topic are related to the theory of the broken-promise effect.
}

writing a will whose terms are contingent on heirs' behavior. Even under this scenario, observing a death elasticity may be considered as evidence against the pure life-cycle model, and in favor of a model with a strategic bequest motive.

\section{Institutional Background}

\section{A. Estate Tax}

The modern U.S. estate tax was introduced in 1916. Initially, the highest marginal tax rate was just $10 \%$, on estates above $\$ 50,000,000$. The tax rates were increased twice during 1917, and then they were reduced in 1919 and 1926. Starting in 1932, a series of five consecutive tax reforms increased the top marginal tax rates to $77 \%$. At that level the tax rates stayed until 1976. Between 1977 and 1987 the exemption level changed every year. The Tax Reform Act of 1976 and the Economic Recovery Act of 1981 also modified the rate structure (the latter was phased in over three years).

\section{B. Estate-Tax Changes}

We examine the timing of deaths resulting in taxable estates in the period surrounding 13 major changes in the estate tax. ${ }^{4}$ Eight of them $(3 / 3 / 1917,10 / 4 / 1917,6 / 2 / 1924$, $6 / 6 / 1932,5 / 10 / 1934,8 / 30 / 1935,6 / 26 / 1940,9 / 20 / 1941$ ) were tax increases, and five of them were tax decreases $(2 / 24 / 1919,2 / 26 / 1926,10 / 21 / 1942,1 / 1 / 1983,1 / 1 / 1984)$. These tax reforms involved changes in the tax structure, and occasionally also in the exemption level (but always with the same direction of changes in tax liability for all estates).

The chronology of events leading to the tax changesand therefore the degree to which the effective date might have been anticipated-varied somewhat. The pre-1980s reforms took effect on the day they were signed by the president. Our reading of newspaper accounts of the time suggests that once the House and Senate conference agreed on the tax bill, that the president would sign it was a foregone conclusion. As the chronology in Table Al shows, the elapsed time between the two dates ranged from 2 to 18 days, and averaged 6.6 days. The time between the passage of a tax bill in the Senate and presidential signature ranged from 5 to 63 days, and averaged 19.1 days. The generally swift procedure strongly suggests that the effective date of the prewar tax bills could to some varying extent be anticipated. The timing and content of reforms of the 1980 s were known in advance, because they were part of legislation

\footnotetext{
4These are the reforms that involved significant changes in the tax rate structure, as identified by McCubbin (1990) and Luckey (1995). Because of the incomplete coverage of our data detailed in section III, we cannot analyze a few tax reforms, such as the changes in the rate structure and exemption level between 1977 and 1982. Because of data deficiencies related to inconsistent sampling rules across years, we also do not examine changes in the exemption level between 1985 and 1987 and a small modification of the tax rate structure introduced by the Omnibus Budget Reconciliation Act of 1987 that applied only to very large estates (above $\$ 10,000,000$ ).
} 
designed to gradually increase the tax credit and phase out high marginal tax rates.

The changes in tax law usually involved more than just a change in the tax rate structure. On a few occasions the definition of taxable estate changed, and we take account of that in the analysis below. Occasionally, the definition of gross and net estates changed as well. This is relevant because the filing requirement is expressed in those terms, so that some size classes of estates would appear in the data before but not after a tax reform, or vice versa. As mentioned below, we deal with this issue by considering only those returns with a reported net worth that is above the larger of the pre- and postreform thresholds.

\section{Data}

Our analysis makes use of an extraordinary sample of estate-tax returns filed from the inception of the modern U.S. tax until very recently. This database contains most of the information from estate-tax returns filed in every year between 1916 and 1945, as well as returns filed in 1962 , $1965,1969,1972,1976$, and all years between 1982 and 1996. For the years 1916 to 1945 , all the returns actually filed in those years (provided they were not missing at the time the data were entered in the database) are included. The postwar data are a stratified sample of all returns filed, with sampling probabilities available to enable us to statistically represent the unsampled returns as well. McCubbin (1990) describes the origin and structure of the data in detail.

The information requested on the tax return changed over time, as did the items from the returns that were placed in the data set. In one key respect, the data for the pre-1945 period are better: information on the day of death is available for every individual, so that it is possible to identify a complete population of individuals dying close to any tax reform. The postwar tax reforms coincide with the beginning of the year, and thus in every case also correspond to differences in the sampling procedure. ${ }^{5,6}$

\section{Aggregate Analysis}

We begin with the simplest possible approach for detecting the effect of estate-tax changes on the reported dates of deaths: observing the number of returns filed that report dates of death within a period of days before and after the

\footnotetext{
5 As noted earlier, there may also be nontax behavioral responses with regard to end-of-year deaths. We return this issue later.

${ }^{6}$ The sampling procedure used in choosing estates filed in 1985 differed from those for other years. In particular, no individuals who were older than 45 and had estates below $\$ 5$ million were sampled. Most tax returns are filed within 3 years of decedent's death (more than $99 \%$, according to Johnson, 1994), so that it is unclear if data between 1982 and 1985 are representative. For this reason and we do not include this data in the pooled specification.
}

tax reform. Because for later years the sampling procedure changed exactly at the time when tax reforms were implemented, we analyze in this way only the pre-1945 reforms.

In order to make this comparison meaningful, tax returns before and after a tax reform need to be drawn from the same population. For that reason we investigate only those returns with a reported net worth above the larger of the preand postreform filing thresholds. Implicitly, this amounts to treating net worth around the tax reform as exogenous. This assumption would be unacceptable for analysis over a longer period, but it seems to be reasonable to make it for an analysis of the decisions regarding a short of period as we do here.?

Some of the pre-1945 tax reforms did not take effect at midnight. Instead, the law specified a precise time of day other than midnight when the new law started to apply. As a result, returns filed for decedents who passed away on the day of the reform may be subject to either of the two statutes. $^{8}$ For this reason, for these reforms ${ }^{9}$ we exclude from the analysis returns that report the reform date as the date of death.

Table 1 summarizes this data. As a basis of comparison, it first gives the number of tax returns filed reporting the date of death to be the day of the tax reform. Then it reports the average number of returns with date of death within 1, 3,7 , and 14 days of the tax reform. The averages do not include the day of the reform. The table contains $t$-statistics and $p$-values for the mean of the number of returns filed within a given number of days from the tax reform in the lower-tax regime to be greater than of those filed in the higher-tax regime. ${ }^{10}$ Note that reforms of 1919, 1926, and 1942 are tax decreases (denoted by D in the third column of the table) and the others are tax increases (denoted I).

There is some evidence for the presence of a death elasticity for the 14-day window. The tests for differences in the means are significant at the $10 \%$ level, and in the expected direction, for the reforms of $3 / 3 / 1917,1926,1934$, and 1942. This includes two out of the three tax decreases for this period. This pattern is particularly interesting in that one might expect the behavioral response to tax decreases to be stronger: it is more plausible that people live longer to lower estate taxes than that they die sooner to save taxes. The evidence for shorter windows is less clear, which is not surprising in light of the small number of observations.

The foregoing analysis of dates of death makes no use of

\footnotetext{
${ }^{7}$ In other work (Kopczuk \& Slemrod, 2001), we examine the effect of the estate tax on the value of reported estates.

${ }^{8}$ It was not possible to ascertain precisely which law was applicable from the magnitude of the estate and the reported tax liability, because the tax-liability variable available in the data set was reduced by certain credits whose magnitude is not known.

${ }^{9}$ These are the reforms of 1919, 1924, 1926, 1932, 1934, 1935, 1940, 1941 , and 1942.

${ }^{10}$ This is a standard one-sided $t$-test for equality of the means of two populations (here, the average numbers of deaths before and after the tax reform), with standard deviations calculated based on a 30-day window.
} 
Table 1.-Average Number of Decedents Dying within 1, 3, 7, and 14 Days of Tax Reforms

\begin{tabular}{|c|c|c|c|c|c|c|c|c|}
\hline $\begin{array}{c}\text { Reform } \\
\text { Date }\end{array}$ & & $\begin{array}{l}\text { Day of } \\
\text { Reform }\end{array}$ & & $\begin{array}{l}\text { Within } \\
1 \text { Day }\end{array}$ & $\begin{array}{l}\text { Within } \\
3 \text { Days }\end{array}$ & $\begin{array}{l}\text { Within } \\
7 \text { Days }\end{array}$ & $\begin{array}{l}\text { Within } \\
14 \text { Days }\end{array}$ & $\begin{array}{l}\text { Standard } \\
\text { Deviation }\end{array}$ \\
\hline \multirow[t]{3}{*}{$03 / 03 / 1917$} & I & 28 & $\begin{array}{l}\text { Before } \\
\text { After }\end{array}$ & $\begin{array}{l}27 \\
23\end{array}$ & $\begin{array}{l}24.67 \\
23.00\end{array}$ & $\begin{array}{l}23.86 \\
20.57\end{array}$ & $\begin{array}{l}24.93 \\
22.21\end{array}$ & $\begin{array}{l}5.61 \\
4.55\end{array}$ \\
\hline & & & $t$-Stat. & 0.55 & 0.40 & 1.20 & 1.41 & \\
\hline & & & $p$-Value & 0.29 & 0.35 & 0.12 & 0.08 & \\
\hline \multirow[t]{4}{*}{$10 / 04 / 1917$} & I & 12 & Before & 23 & 19.33 & 21.14 & 20.00 & 5.06 \\
\hline & & & After & 20 & 15.67 & 19.43 & 18.86 & 4.79 \\
\hline & & & t-Stat. & 0.43 & 0.91 & 0.65 & 0.61 & \\
\hline & & & $p$-Value & 0.33 & 0.18 & 0.26 & 0.27 & \\
\hline \multirow[t]{4}{*}{$02 / 24 / 1919$} & D & 21 & Before & 36 & 29.67 & 27.14 & 28.21 & 7.53 \\
\hline & & & After & 35 & 33.00 & 31.00 & 29.93 & 5.33 \\
\hline & & & f-Stat. & 0.11 & 0.63 & 1.11 & 0.70 & \\
\hline & & & $p$-Value & 0.46 & 0.27 & 0.14 & 0.24 & \\
\hline \multirow[t]{4}{*}{$06 / 02 / 1924$} & I & 36 & Before & 35 & 31.67 & 33.29 & 30.64 & 5.02 \\
\hline & & & After & 29 & 31.00 & 33.57 & 31.64 & 5.60 \\
\hline & & & t-Stat. & 0.80 & 0.15 & 0.10 & 0.50 & \\
\hline & & & $p$-Value & 0.21 & 0.44 & 0.46 & 0.31 & \\
\hline \multirow[t]{4}{*}{$02 / 26 / 1926$} & D & 16 & Before & 23 & 20.33 & 18.57 & 18.43 & 4.08 \\
\hline & & & After & 17 & 19.00 & 19.71 & 20.86 & 4.65 \\
\hline & & & $t$-Stat. & 0.97 & 0.37 & 0.49 & 1.47 & \\
\hline & & & $p$-Value & 0.17 & 0.36 & 0.31 & 0.07 & \\
\hline \multirow[t]{4}{*}{$06 / 06 / 1932$} & 1 & 10 & Before & 9 & 7.67 & 9.14 & 10.14 & 3.46 \\
\hline & & & After & 15 & 10.33 & 9.57 & 9.50 & 3.42 \\
\hline & & & I-Stat. & -1.23 & -0.95 & -0.23 & 0.49 & \\
\hline & & & $p$-Value & 0.89 & 0.83 & 0.59 & 0.31 & \\
\hline \multirow[t]{4}{*}{$05 / 10 / 1934$} & $I$ & 26 & Before & 20 & 24.67 & 26.71 & 28.00 & 4.94 \\
\hline & & & After & 24 & 23.67 & 24.86 & 24.29 & 5.02 \\
\hline & & & t-Stat. & 0.57 & 0.25 & 0.70 & 1.97 & \\
\hline & & & $p$-Value & 0.29 & 0.40 & 0.24 & 0.03 & \\
\hline \multirow[t]{4}{*}{$08 / 30 / 1935$} & I & 28 & Before & 26 & 28.00 & 26.29 & 25.29 & 4.07 \\
\hline & & & After & 21 & 24.00 & 25.29 & 26.64 & 5.39 \\
\hline & & & t-Stat. & 0.74 & 1.03 & 0.39 & -0.75 & \\
\hline & & & $p$-Value & 0.23 & 0.15 & 0.35 & 0.77 & \\
\hline \multirow[t]{4}{*}{$06 / 25 / 1940$} & I & 40 & Before & 36 & 35.67 & 35.00 & 35.00 & 5.36 \\
\hline & & & After & 36 & 35.00 & 36.57 & 35.07 & 6.90 \\
\hline & & & t-Stat. & 0.00 & 0.13 & -0.48 & -0.03 & \\
\hline & & & $p$-Value & 0.50 & 0.45 & 0.68 & 0.51 & \\
\hline \multirow[t]{4}{*}{$09 / 20 / 1941$} & I & 31 & Before & 30 & 34.67 & 35.86 & 37.21 & 7.40 \\
\hline & & & After & 35 & 40.67 & 37.57 & 38.86 & 6.33 \\
\hline & & & t-Stat. & -0.51 & -1.07 & -0.47 & -0.63 & \\
\hline & & & $p$-Value & 0.70 & 0.84 & 0.68 & 0.73 & \\
\hline \multirow[t]{4}{*}{$10 / 21 / 1942$} & D & 32 & Before & 33 & 25.33 & 29.14 & 28.50 & 5.09 \\
\hline & & & After & 43 & 38.67 & 34.43 & 34.79 & 6.07 \\
\hline & & & t-Stat. & 1.26 & 2.92 & 1.77 & 2.97 & \\
\hline & & & $p$-Value & 0.11 & 0.00 & 0.04 & 0.00 & \\
\hline
\end{tabular}

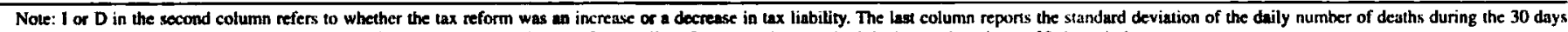
before and after a reform. The r-statistics and p-values are obtained using test for equality of means using standard deviations based on a 30 -day window.

the fact that the financial incentive to postpone or accelerate death or its reported date varies greatly across the reforms, and across individuals for a given reform. To investigate this issue we calculate, for every individual with a reported date of death close to a tax reform, the tax liability under the old and new tax systems; one of these figures is a counterfactual, or hypothetical, tax liability. (Details of the calculation are presented in the appendix.) The difference between these two tax liabilities is our measure of the tax incentive regarding the time of death.

Table 2 presents some summary information about the average and median tax incentive, or potential savings, for people who died before and after a given tax reform. Only individuals who could have saved a positive amount are included. "It is clear that the potential tax saving is much higher for some of the tax changes, in particular 1932, 1934, 1935 , and 1942. In some cases $(1935,1941,1942)$, the mean tax savings before and after the tax change are statistically significantly different. In 1935 and 1942 the mean tax saving is higher in the low-tax regime, but in 1942 it is

\footnotetext{
"Most of the reforms affected almost everyone subject to tax. Exceptions are: the reforms of 1924 and 1934, which each increased only the top rates without affecting tax rates for smaller estates (30\% and $38 \%$ of our sample had potential tax savings, respectively) and the 1980s reforms, when the unlimited marital deduction was in place $(60-70 \%$ of our sample had positive savings). During the remaining nine reforms, more than $98 \%$ of our sample had potential changes in tax liability. In the regression analysis that we report later in the paper. we include individuals with zero potential savings.
} 
TABle 2.-Descruptive Statistics for the Estate-TAx Reforms

\begin{tabular}{|c|c|c|c|c|c|c|c|}
\hline & \multirow[b]{2}{*}{ Reform Date } & & \multicolumn{2}{|c|}{ Number of Individuals } & \multicolumn{3}{|c|}{ Tax Saving (current dollars) } \\
\hline & & & Weighted & Unweighted & Median & Mean & Std. Dev. \\
\hline \multirow[t]{2}{*}{$3 / 3 / 1917$} & I & Before & 349 & 349 & 285.8 & 4,456 & 1.114 \\
\hline & & After & 318 & 318 & 225.9 & 4.471 & 1.608 \\
\hline \multirow[t]{2}{*}{$10 / 4 / 1917$} & I & Before & 280 & 280 & 256.8 & 4,142 & 783 \\
\hline & & After & 260 & 260 & 186.1 & 3.271 & 1,406 \\
\hline \multirow[t]{2}{*}{$02 / 24 / 1919^{*}$} & $\mathrm{D}$ & Before & 392 & 392 & 417.5 & 3,560 & 419 \\
\hline & & After & 416 & 416 & 632.6 & 3.609 & 391 \\
\hline \multirow[t]{2}{*}{$02 / 06 / 1924^{*}$} & 1 & Before & 132 & 132 & $1,071.3$ & 77,122 & 62.153 \\
\hline & & After & 126 & 126 & 1.102 .4 & 12.110 & 7,319 \\
\hline \multirow[t]{2}{*}{$02 / 26 / 1926^{*}$} & $\mathrm{D}$ & Before & 257 & 257 & $1,389.2$ & 18,674 & 7,352 \\
\hline & & After & 288 & 288 & $1,313.9$ & 21,761 & 7,183 \\
\hline \multirow[t]{2}{*}{$06 / 06 / 1932 *$} & I & Before & 141 & $1+1$ & $5,788.7$ & 14,056 & 2.332 \\
\hline & & After & 132 & 132 & $5,851.7$ & 15.895 & 2.392 \\
\hline \multirow[t]{2}{*}{$05 / 10 / 1934^{*}$} & I & Before & 156 & 156 & $3,247.1$ & 35,360 & 11,869 \\
\hline & & After & 124 & 124 & $4,235.3$ & 21,059 & 8,366 \\
\hline \multirow[t]{2}{*}{$08 / 30 / 1935^{*}$} & 1 & Before & 348 & 348 & 2.732 .0 & 8,032 & 829 \\
\hline & & After & 366 & 366 & 2.037 .5 & 6,345 & 618 \\
\hline \multirow[t]{2}{*}{$06 / 25 / 1940^{*}$} & I & Before & 483 & 483 & 140.4 & 1,599 & 324 \\
\hline & & After & 483 & 483 & 192.4 & 2,417 & 1,066 \\
\hline \multirow[t]{2}{*}{$09 / 20 / 1941 *$} & 1 & Before & 508 & 508 & $1,929.6$ & 10,017 & 965 \\
\hline & & After & 535 & 535 & 1.563 .6 & 8.235 & 1.120 \\
\hline \multirow[t]{2}{*}{$10 / 21 / 1942^{*}$} & D & Before & 390 & 390 & $5,211.4$ & 4,630 & 95 \\
\hline & & After & 482 & 482 & 4.688 .1 & 4.404 & 79 \\
\hline \multicolumn{8}{|c|}{ Reforms of the $1980 \mathrm{~s}$} \\
\hline \multirow[t]{2}{*}{$01 / 01 / 1983$} & D & Before & 1512.3 & 557 & 16.500 .0 & 16.146 & 810 \\
\hline & & After & 1672.9 & 53 & 16.500 .0 & 17,895 & 2.949 \\
\hline \multirow[t]{2}{*}{$01 / 01 / 1984$} & D & Before & 1345.4 & 40 & $17,000.0$ & 17,070 & 6,489 \\
\hline & & After & 1870.8 & 49 & $17,000.0$ & 23.131 & 23.786 \\
\hline
\end{tabular}

- Day of the reform is excluded.

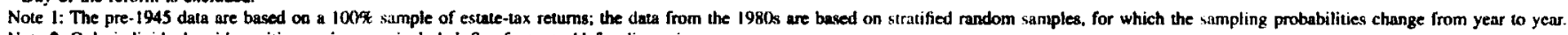
Note 2: Only individuals with positive savings ane included. See foomote $\mid I$ for disiussion

Note 3: The numbers are for individuals dying within I4 deys of the tax reform.

higher in the high-tax regime. Overall, means and medians of tax savings do not suggest that the behavioral response, if any, should be concentrated among the richer part of the sample.

A comparison of means and medians in table 2 suggests that the distribution of potential tax saving is highly skewed. This is especially obvious for the reform of 1924 , when the medians are very close, but mean tax savings are very different. This suggests that one has to be careful to make sure that outliers do not unduly affect the conclusions.

Table 3 contains more information about the potential tax saving of different tax reforms. Mean savings in constant 1945 dollars (multiplying by 9.63 yields 2000 dollars) are shown, as well as the average ratio of the potential tax saving to the individual's net worth. The reforms vary significantly in the magnitudes of potential savings, ranging from $\$ 2,577$ in 1940

Table 3.-Mean and Median Potential Tax Saving, Overall and by Tax Reform

\begin{tabular}{|c|c|c|c|c|c|}
\hline & & \multicolumn{2}{|c|}{ Mean Tax Saving } & \multicolumn{2}{|c|}{ Median Tax Saving } \\
\hline \multicolumn{2}{|c|}{ Reform Date } & $\begin{array}{c}\text { Value } \\
\text { (1945\$) }\end{array}$ & $\begin{array}{c}\text { Share in Net } \\
\text { Worth (\%) }\end{array}$ & $\begin{array}{c}\text { Vaiue } \\
(1945 \$)\end{array}$ & $\begin{array}{l}\text { Share in Net } \\
\text { Worth (\%) }\end{array}$ \\
\hline All (except 1 & & 10,772 & 1.8 & 1,532 & 0.9 \\
\hline \multicolumn{6}{|c|}{ By Reform } \\
\hline $3 / 3 / 1917$ & l & 6,265 & 0.5 & 358 & 0.3 \\
\hline $10 / 4 / 1917$ & I & 5,226 & 0.5 & 308 & 0.2 \\
\hline $2 / 24 / 1919$ & D & 3,731 & 0.8 & 505 & 0.5 \\
\hline $6 / 2 / 1924$ & I & 47,765 & 0.8 & 1,129 & 0.4 \\
\hline $2 / 26 / 1926$ & D & 20,650 & 1.2 & 1,378 & 0.7 \\
\hline $6 / 6 / 1932$ & I & 19,696 & 3.7 & 7.629 & 3.4 \\
\hline $5 / 10 / 1934$ & I & 39,015 & 2.0 & 4,701 & 1.4 \\
\hline $8 / 30 / 1935$ & 1 & 9,399 & 2.5 & 3.133 & 2.3 \\
\hline $6 / 25 / 1940$ & 1 & 2,577 & 0.4 & 211 & 0.2 \\
\hline $9 / 20 / 1941$ & $i$ & 11.126 & 3.5 & 2.106 & 2.4 \\
\hline $10 / 21 / 1942$ & D & 4,976 & 3.4 & 5,302 & 3.6 \\
\hline \multicolumn{6}{|c|}{ Reforms of the $1980 \mathrm{~s}$} \\
\hline $1 / 1 / 1983$ & D & 3,130 & 2.9 & 3,078 & 1.6 \\
\hline $1 / 1 / 1984$ & D & 3,583 & 3.1 & 3,073 & 2.5 \\
\hline
\end{tabular}


Table 4.-Probability of Dying in the Low-Tax Regime as a Function of Potential. Tax Saving

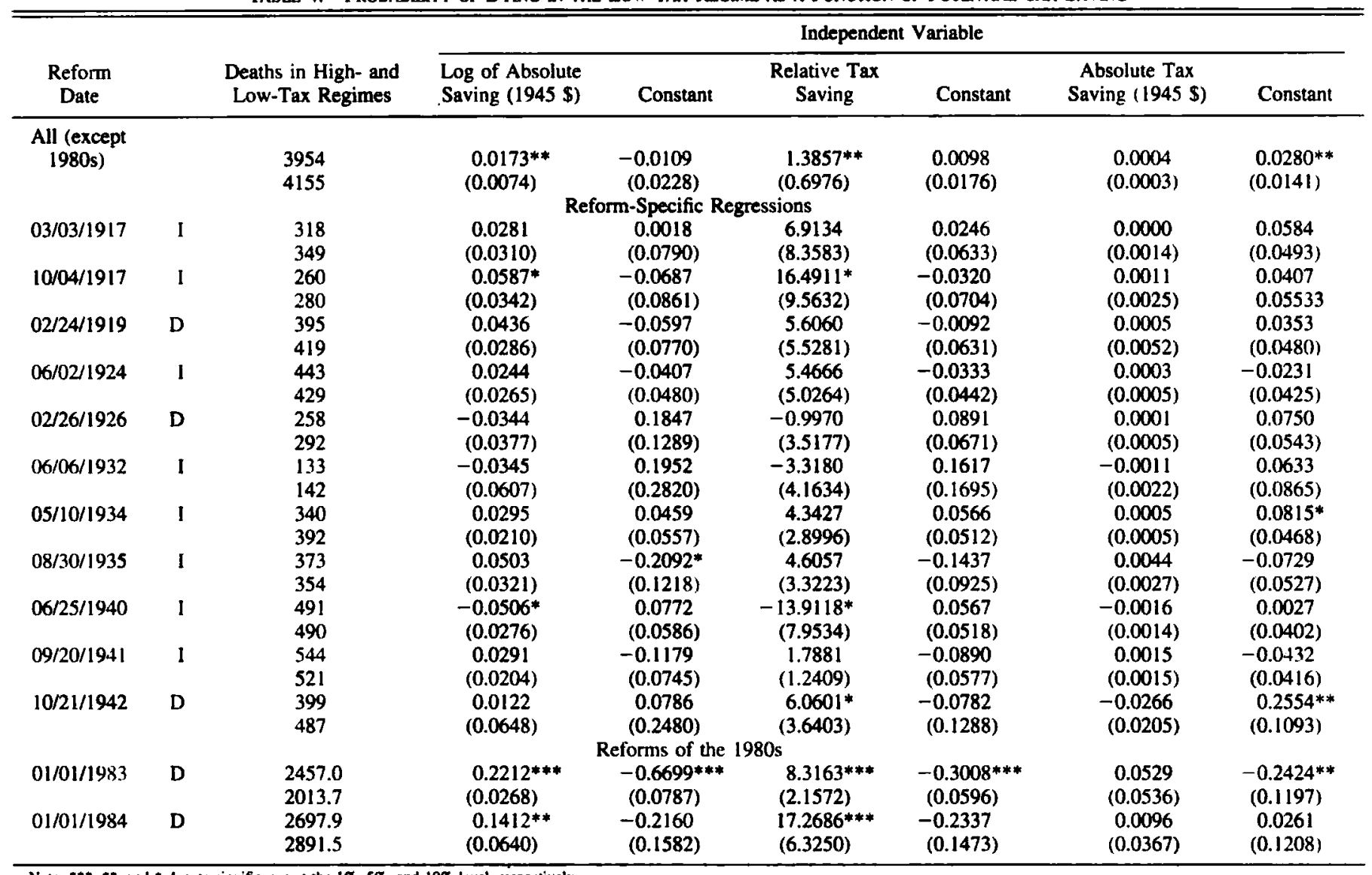

Note: ***." ". and " denote significance at the 1\%, 5\%. and 10\% level. respectively.

to $\$ 47,765$ in 1924 . The medians also vary quite a bit, from $\$ 308$ in 1917 to $\$ 7,629$ in 1932 . In most cases, the medians are significantly smaller than the means. The mean ratio of saving to net worth also varies significantly, from $0.4 \%$ to $3.7 \%$. The medians range from $0.2 \%$ to $3.6 \%$.

\section{Micro Regression Analysis}

If the (reported) date of death responds to tax changes, one should observe that the probability of dying in the low-tax regime is a function of the tax saving from so doing. To test this hypothesis, we run a series of probit regression analyses spanning a short window around estate-tax changes, with the sole right-side variable being a measure of the potential tax saving from dying in the low-tax regime, which may be before or after the tax law change. ${ }^{12}$ Thus, we are examining whether the probability of dying in the low-tax regime, whether that is before or after a tax change, depends on the tax saving from dying then rather than dying during the high-tax regime.

\footnotetext{
${ }^{12}$ For each reform, taxes for all individuals change in the same direction. Therefore, for each reform it is unambiguous to refer to one of the tax regimes as the high-tax one and to the other as the low-tax one. For individuals whose tax liability is the same under either regime, we set the low-tax dummy according to the time of their death. In a sense, people with zero tax saving constitute a natural control group.
}

We compute and examine three different measures of tax saving: (1) the absolute value of the potential tax saving (in 1945 dollars); (2) the tax saving expressed as a fraction of the decedent's net worth, and (3) the logarithm of the absolute tax saving (in 1945 dollars) plus $\$ 100 .{ }^{13}$ We pursue the last two measures in order to reduce the influence of large outlying values, and because we suspect that the incentive of any dollar amount of tax saving may be smaller the larger is the overall size of the estate.

We first pool all of the data, and then separately analyze the data for each tax change. ${ }^{14}$ Table 4 reports the resuits for deaths that occurred within 14 days of the tax reform. The third column of this table shows the number of individuals who died in the high and low tax regimes for each reform. respectively. The pooled regressions suggest that there may be a significant death elasticity. When the tax saving is measured either in log terms or as a fraction of net worth,

\footnotetext{
${ }^{13}$ More precisely, this variable is defined as $\log (100+$ saving $)-\log (100)$, so that it equals zero when there is no potential tax saving.

14 We use sampling weights in the regressions. This matters only for the reforms of 1983 and 1984 . The results when weights are not used share the qualitative features of the ones presented here. We report the robust standard errors. In the regressions the tax savings are expressed in real (1945) dollars. The pooled regression does not include the reforms of the 1980 s. The results when they are included show stronger behavioral response than what is reported in the pooled results excluding the 1980s.
} 
there is a statistically significant relationship between the probability of dying in the low-tax period and the tax saving from so doing. The probit coefficients imply ${ }^{15}$ that a $1 \%$ increase in the ratio of tax saving to wealth would increase the probability of dying in the low-tax period by $0.6 \%$. In the logarithmic specification, a $\$ 10,000$ tax saving (using 2000 dollars, which corresponds to $\$ 1034$ in 1945) is associated with an increase of $1.7 \%$ in the probability of dying in the low-tax period. We find no significant relationship for the absolute tax saving specification, which we suspect is due to the noise introduced by large outlying values of the potential tax saving.

The results for individual tax reforms are not nearly as strong, although most of the estimated coefficients have the "right," that is, positive sign. Of the thirteen tax reforms we study, the coefficients are of expected sign in ten cases for each of the specifications. If the coefficient is truly zero, estimated coefficients should be positive and negative with equal probability. The probability of observing at least that many positive coefficients is $4.6 \%$. Treating these thirteen reforms as draws from the same distributions, for each of the three measures of potential tax saving the hypothesis of no effect may be rejected at a 5\% level of significance. although for many reforms the magnitude of the effect is not statistically different from zero.

The measured behavioral response is most pronounced for the two reforms of the 1980s, when the sampling procedure was not consistent in adjacent years. The returns were sampled every year, but the procedure was designed to achieve a representative sample of decedents dying in 1982 and 1986, so that returns filed in these years were oversampled. Although the population weights for other years were constructed to replicate the actual distribution of net worth of decedents, the precise sampling properties for those years are not known. In particular we are not sure if the sample is representative of the individuals dying during the short period we consider. This problem is not present for the pre-1945 reforms. ${ }^{16}$

Note that the reform-by-reform regressions allow for not only reform-specific tax coefficients but also reformspecific constant terms. In fact, there is a significant seasonal pattern of mortality during a year, with a peak during the winter months and a trough in August and September. Although the estimated constants in the reform-specific regressions are supposed to take account of this effect, the

\footnotetext{
is The marginal effects are evaluated at zero tax savings.

16 In order to check the robustness of our results, we experimented with different windows around the tax reform. The pooled results for a one-week window were insignificant, although with "correct" positive signs in each case. and the results for just the second week were significant. We suspect that this may be due to significant uncertainty regarding the date of enacting the reform, which makes planning the exact timing more difficult. In order to make sure that we are not simply picking up some other permanent effect of changes in tax law, we compared the third week into the low-tax regime with the third week into the high-tax regime. The results were insignificant, and were also of the "wrong" sign in two out of three specifications. The same was true for the fourth week.
}

Table 5.-Probability of Dying in the Low-Tax Regimes as a Function of Potential Tax Saving: Pooled Regressions Allowing for Different Seasonal Patterns Across Reporms

\begin{tabular}{|c|c|c|c|c|}
\hline \multirow[b]{2}{*}{ Tax Reform } & & \multicolumn{3}{|c|}{ Independent Variable } \\
\hline & & $\begin{array}{l}\text { Log of Absolute } \\
\text { Saving (1945\$) }\end{array}$ & $\begin{array}{l}\text { Relative Tax } \\
\text { Saving }\end{array}$ & $\begin{array}{c}\text { Absolute Tax } \\
\text { Saving (1945 \$) }\end{array}$ \\
\hline $\begin{array}{l}\text { Tax saving } \\
\text { coefficient }\end{array}$ & & $\begin{array}{l}0.0175^{* * *} \\
0.0087\end{array}$ & $\begin{array}{l}2.1459 * * \\
(0.9043)\end{array}$ & $\begin{array}{c}0.0004 \\
(0.0003)\end{array}$ \\
\hline $03 / 03 / 1917$ & I & $\begin{array}{l}\text { Rerom D } \\
0.0230 \\
(0.0516)\end{array}$ & $\begin{array}{c}\text { mmies } \\
0.0478 \\
(0.0488)\end{array}$ & $\begin{array}{c}0.0560 \\
(0.0486)\end{array}$ \\
\hline $10 / 04 / 1917$ & I & $\begin{array}{c}0.0120 \\
(0.0566)\end{array}$ & $\begin{array}{c}0.0362 \\
(0.0541)\end{array}$ & $\begin{array}{c}0.0446 \\
(0.0540)\end{array}$ \\
\hline $02 / 24 / 1919$ & $\mathrm{D}$ & $\begin{array}{c}0.0289 \\
(0.0475)\end{array}$ & $\begin{array}{c}0.0499 \\
(0.0440)\end{array}$ & $\begin{array}{c}0.0663 \\
(0.0434)\end{array}$ \\
\hline $06 / 02 / 1924$ & I & $\begin{array}{c}-0.0840^{* *} \\
(0.0423)\end{array}$ & $\begin{array}{r}-0.0743^{*} \\
(0.0417)\end{array}$ & $\begin{array}{c}-0.0720^{*} \\
(0.0417)\end{array}$ \\
\hline $02 / 26 / 1926$ & D & $\begin{array}{c}0.0566 \\
(0.0593)\end{array}$ & $\begin{array}{c}0.0864 \\
(0.0538)\end{array}$ & $\begin{array}{c}0.1038^{*} \\
(0.0530)\end{array}$ \\
\hline $06 / 06 / 1932$ & I & $\begin{array}{c}-0.0828 \\
(0.0839)\end{array}$ & $\begin{array}{c}-0.0824 \\
(0.0813)\end{array}$ & $\begin{array}{c}-0.0115 \\
(0.0744)\end{array}$ \\
\hline $05 / 10 / 1934$ & I & $\begin{array}{c}0.0172 \\
(0.0206)\end{array}$ & $\begin{array}{c}0.0267 \\
(0.0461)\end{array}$ & $\begin{array}{c}0.0379 \\
(0.0457)\end{array}$ \\
\hline $08 / 30 / 1935$ & I & $\begin{array}{c}-0.1394^{* *} \\
(0.0549)\end{array}$ & $\begin{array}{c}-0.1297 * * \\
(0.0505)\end{array}$ & $\begin{array}{c}-0.0814^{*} \\
(0.0457)\end{array}$ \\
\hline $06 / 25 / 1940$ & I & $\begin{array}{c}-0.0778^{*} \\
(0.0416)\end{array}$ & $\begin{array}{c}-0.0594 \\
(0.0394)\end{array}$ & $\begin{array}{c}-0.0513 \\
(0.0393)\end{array}$ \\
\hline 09/20/1941 & I & $\begin{array}{c}-0.1167^{* *} \\
(0.0467)\end{array}$ & $\begin{array}{c}-0.1363^{* * *} \\
(0.0493)\end{array}$ & $\begin{array}{c}-0.0657^{*} \\
(0.0380)\end{array}$ \\
\hline $10 / 2 \mathrm{~L} / 1942$ & D & $\begin{array}{c}0.0984^{*} \\
(0.0530)\end{array}$ & $\begin{array}{c}0.0927^{*} \\
(0.0514)\end{array}$ & $\begin{array}{l}0.1628^{* * *} \\
(0.0416)\end{array}$ \\
\hline
\end{tabular}

Note: ***, **, and * denote significance at the $1 \%, 5 \%$, and $10 \%$ level, respectively.

Each column contains results of a separate regression of the bow-tax indicator on one of the tax measures and reform dummies.

pooled regression essentially forces these constants to be identical, which amounts to ignoring the seasonal pattern. As a robustness check on the importance of seasonality, in table 5 we report the results of reestimating the pooled specification while allowing reform-specific dummies that could allow for seasonal effects. It is reassuring that the estimated tax saving coefficients are very close to the ones reported in table 4 and with identical pattern of significance.

Additionally, we could presumably sharpen our estimates if the values of constants were known. ${ }^{17}$ There are data on aggregate mortality experience, and, assuming that the mortality experience of the estate tax filers follows the same pattern, they can be used to determine the value of the constants when tax savings are not present. In implementing this strategy, we used the data on the monthly aggregate mortality rates from the U.S. Department of Commerce to come up with the values of constants representing the mortality changes during periods under consideration. Our procedure is described in the appendix. We pursued this approach only for the pre-1945 reforms, because we are not confident that the numbers of deaths in our sample for the $1980 \mathrm{~s}$ reforms are representative. The restricted values of

\footnotetext{
${ }^{17}$ If the true effect is nonlinear, not restricting the constants may be a preferred approach.
} 
Table 6.-Probability of Dying in the Low-Tax Regime as a Function of Potential Tax Saving: Reform-Specific Regressions with a Constant Restriction Based on the Aggregate Pattern of Deaths

\begin{tabular}{|c|c|c|c|c|c|c|}
\hline \multirow[b]{2}{*}{$\begin{array}{c}\text { Reform } \\
\text { Date }\end{array}$} & & \multirow{2}{*}{$\begin{array}{l}\text { Deaths in } \\
\text { High- and } \\
\text { Low-Tax } \\
\text { Regimes }\end{array}$} & \multirow[b]{2}{*}{$\begin{array}{l}\text { Restriction on } \\
\text { the Constant }\end{array}$} & \multicolumn{3}{|c|}{ Independent Variable } \\
\hline & & & & $\begin{array}{l}\text { Log of Absolute } \\
\text { Saving (1945 \$) }\end{array}$ & $\begin{array}{l}\text { Relative Tax } \\
\text { Saving }\end{array}$ & $\begin{array}{c}\text { Absolute Tax } \\
\text { Saving (1945 \$) }\end{array}$ \\
\hline $03 / 03 / 1917$ & I & $\begin{array}{l}318 \\
349\end{array}$ & 0.0209 & $\begin{array}{c}0.0222 \\
(0.0190)\end{array}$ & $\begin{array}{c}7.2208 \\
(6.4184)\end{array}$ & $\begin{array}{c}0.0002 \\
(0.0044)\end{array}$ \\
\hline $10 / 04 / 1917$ & I & $\begin{array}{l}260 \\
280\end{array}$ & 0.0092 & $\begin{array}{c}0.0346 \\
(0.0214)\end{array}$ & $\begin{array}{l}12.9885^{*} \\
(7.2738)\end{array}$ & $\begin{array}{c}0.0013 \\
(0.0081)\end{array}$ \\
\hline $02 / 24 / 1919$ & D & $\begin{array}{l}395 \\
419\end{array}$ & -0.0167 & $\begin{array}{c}0.0306^{*} \\
(0.0163)\end{array}$ & $\begin{array}{c}6.0721 \\
(3.8512)\end{array}$ & $\begin{array}{c}0.0027 \\
(0.0151)\end{array}$ \\
\hline $06 / 02 / 1924$ & I & $\begin{array}{l}443 \\
429\end{array}$ & 0.0181 & $\begin{array}{c}0.0091 \\
(0.0235)\end{array}$ & $\begin{array}{c}3.6831 \\
(4.7546)\end{array}$ & $\begin{array}{c}0.0003 \\
(0.0011)\end{array}$ \\
\hline $02 / 26 / 1926$ & D & $\begin{array}{l}258 \\
292\end{array}$ & 0.0551 & $\begin{array}{r}0.00001 \\
(0.0156)\end{array}$ & $\begin{array}{c}0.0768 \\
(2.7982)\end{array}$ & $\begin{array}{c}0.0002 \\
(0.0014)\end{array}$ \\
\hline $06 / 06 / 1932$ & I & $\begin{array}{l}133 \\
142\end{array}$ & 0.0157 & $\begin{array}{c}0.0028 \\
(0.0163)\end{array}$ & $\begin{array}{c}-0.1014 \\
(1.8598)\end{array}$ & $\begin{array}{c}-0.0006 \\
(0.0059)\end{array}$ \\
\hline $05 / 10 / 1934$ & $\mathrm{I}$ & $\begin{array}{l}340 \\
392\end{array}$ & 0.0150 & $\begin{array}{l}0.0360^{* * *} \\
(0.0176)\end{array}$ & $\begin{array}{l}5.3273^{* *} \\
(2.6631)\end{array}$ & $\begin{array}{c}0.0007 \\
(0.0017)\end{array}$ \\
\hline $08 / 30 / 1935$ & I & $\begin{array}{l}373 \\
354\end{array}$ & 0.0090 & $\begin{array}{c}-0.0028 \\
(0.0122)\end{array}$ & $\begin{array}{c}-0.1324 \\
(1.6694)\end{array}$ & $\begin{array}{c}0.0025 \\
(0.0074)\end{array}$ \\
\hline $06 / 25 / 1940$ & I & $\begin{array}{l}491 \\
490\end{array}$ & -0.0184 & $\begin{array}{c}-0.0179 \\
(0.0188)\end{array}$ & $\begin{array}{c}-6.6851 \\
(6.0835)\end{array}$ & $\begin{array}{c}-0.0015 \\
(0.0045)\end{array}$ \\
\hline $09 / 20 / 1941$ & 1 & $\begin{array}{l}544 \\
521\end{array}$ & -0.0070 & $\begin{array}{c}0.0030 \\
(0.0105)\end{array}$ & $\begin{array}{c}0.4714 \\
(0.8267)\end{array}$ & $\begin{array}{c}0.0011 \\
(0.0043)\end{array}$ \\
\hline $10 / 21 / 1942$ & D & $\begin{array}{l}399 \\
487\end{array}$ & 0.0100 & $\begin{array}{l}0.0299^{* * *} \\
(0.0110)\end{array}$ & $\begin{array}{l}3.7099 * * * \\
(1.1932)\end{array}$ & $\begin{array}{c}0.0158 \\
(0.0252)\end{array}$ \\
\hline
\end{tabular}

Note: **." and "denote significance at the 1\%, 5\%, and 10\% level, respectively.

constants 18.19 and the corresponding results are shown in table 6 . For the logarithmic and relative specifications, the coefficients for 1942 are significant at the $1 \%$ level and the coefficients for 1934 are significant at the $5 \%$ level. There is also some evidence of an effect for the reforms of 1917 and 1919. The coefficients for the 1940 reform remain positive, but they are no longer significant. Out of eleven prewar reforms, all but two of the tax-saving coefficients are positive for the logarithmic and absolute specifications. If the effect was not present, the probability of estimating at least that many positive coefficients would be $3.3 \%$. For the relative specification, there are three negative coefficients, but two of them (1932 and 1935) are extremely close to zero.

In table 7 , we reestimated the pooled specification of table 5 while allowing for differential response for tax decreases and tax increases. The results for the relative specification remain significant at the $5 \%$ level and the results for the logarithmic specification are significant at the

${ }^{18}$ Apart from the seasonal pattern, there is also significant idiosyncratic variation. For example, mortality was unusually high in late 1918 and early 1919 due to the flu epidemic. For that reason, constants for the reforms occurring at roughly the same time of the year can differ significandy. In interpreting the constants of table 7, one should also note that they reflect the probability of dying in the low-tax regime, which may be before or after the reform, depending on whether the tax change was an increase or a decrease.

${ }^{19}$ For most reforms and specifications, our restrictions cannot be rejected using the coefficient and standard-error estimates from table 6 . For the logarithmic and relative specifications, at a 5\% significance level one can only reject restrictions for 1924, 1935, and 1941. For the absolute specification, the restrictions for 1924, 1935, and 1942 can be rejected at a 5\% level.
Table 7.-Probabilty of Dymo in the Low-tax Regmes as a Function of Potentlal Tax Saving: allowing for Differentlal. Response for tax Increases and Decreases and Different Seasonal Patterns

\begin{tabular}{|c|c|c|c|c|}
\hline \multirow[b]{2}{*}{ Tax Reform } & & \multicolumn{3}{|c|}{ Independent Variable } \\
\hline & & $\begin{array}{l}\text { Log of Absolute } \\
\text { Saving (1945 \$) }\end{array}$ & $\begin{array}{l}\text { Relative Tax } \\
\text { Saving }\end{array}$ & $\begin{array}{c}\text { Absolute Tax } \\
\text { Saving (1945 \$) }\end{array}$ \\
\hline Saving & & $\begin{array}{c}0.0186^{*} \\
(0.0096)\end{array}$ & $\begin{array}{l}2.0213^{* *} \\
(0.9832)\end{array}$ & $\begin{array}{c}0.0005 \\
(0.0004)\end{array}$ \\
\hline Decrease $\times$ saving & & $\begin{array}{c}-0.0061 \\
(0.0232)\end{array}$ & $\begin{array}{c}0.7911 \\
(2.5136)\end{array}$ & $\begin{array}{c}-0.0005 \\
(0.0006)\end{array}$ \\
\hline \multicolumn{5}{|c|}{ Reform Dummies } \\
\hline 03/03/1917 & 1 & $\begin{array}{c}0.0209 \\
(0.0522)\end{array}$ & $\begin{array}{c}0.0484 \\
(0.0488)\end{array}$ & $\begin{array}{c}0.0549 \\
(0.0486)\end{array}$ \\
\hline $10 / 04 / 1917$ & I & $\begin{array}{c}0.0100 \\
(0.0571)\end{array}$ & $\begin{array}{c}0.0368 \\
(0.0541)\end{array}$ & $\begin{array}{c}0.0436 \\
(0.0540)\end{array}$ \\
\hline $02 / 24 / 1919$ & D & $\begin{array}{c}0.0401 \\
(0.0639)\end{array}$ & $\begin{array}{c}0.0445 \\
(0.0474)\end{array}$ & $\begin{array}{c}0.0673 \\
(0.0434)\end{array}$ \\
\hline $06 / 02 / 1924$ & I & $\begin{array}{c}-0.0849 * * \\
(0.0424)\end{array}$ & $\begin{array}{r}-0.0740^{*} \\
(0.0417)\end{array}$ & $\begin{array}{c}-0.0728 * \\
(0.0417)\end{array}$ \\
\hline $02 / 26 / 1926$ & D & $\begin{array}{c}0.0724 \\
(0.0841)\end{array}$ & $\begin{array}{c}0.0788 \\
(0.0589)\end{array}$ & $\begin{array}{l}0.1093 * * \\
(0.0535)\end{array}$ \\
\hline $06 / 06 / 1932$ & I & $\begin{array}{c}-0.0875 \\
(0.0858)\end{array}$ & $\begin{array}{c}-0.0779 \\
(0.0825)\end{array}$ & $\begin{array}{c}-0.0150 \\
(0.0746)\end{array}$ \\
\hline $05 / 10 / 1934$ & I & $\begin{array}{c}0.0156 \\
(0.0477)\end{array}$ & $\begin{array}{c}0.0277 \\
(0.0461)\end{array}$ & $\begin{array}{c}0.0355 \\
(0.0458)\end{array}$ \\
\hline $08 / 30 / 1935$ & I & $\begin{array}{l}-0.1431^{* *} \\
(0.0566)\end{array}$ & $\begin{array}{c}-0.1267^{* *} \\
(0.0514)\end{array}$ & $\begin{array}{c}-0.0830^{*} \\
(0.0458)\end{array}$ \\
\hline $06 / 25 / 1940$ & I & $\begin{array}{c}-0.0795^{*} \\
(0.0421)\end{array}$ & $\begin{array}{c}-0.0589 \\
(0.0395)\end{array}$ & $\begin{array}{c}-0.0517 \\
(0.0393)\end{array}$ \\
\hline $09 / 20 / 1941$ & I & $\begin{array}{c}-0.1200^{* *} \\
(0.0484)\end{array}$ & $\begin{array}{c}-0.1320^{* * *} \\
(0.0511)\end{array}$ & $\begin{array}{c}-0.0676^{*} \\
(0.0381)\end{array}$ \\
\hline $10 / 21 / 1942$ & D & $\begin{array}{c}0.1177 \\
(0.0901)\end{array}$ & $\begin{array}{c}0.0704 \\
(0.0880)\end{array}$ & $\begin{array}{l}0.1642^{* * * *} \\
(0.0416)\end{array}$ \\
\hline
\end{tabular}

Note: "*"."*, and " denote significance at the $1 \%, 5 \%$, and $10 \%$ level, respectively. Each column contains results of a sepante regression of the low-tax indicator on one of the tax measures (allowing for different response for tax increases and decreases) and reform dummies. 
Table 8.-Probability of Dying in the Low-Tax Regime as a Fraction of Potential. Tax Saving: Regressions Using Addmonal Indicators

\begin{tabular}{lccc}
\hline \hline \multicolumn{1}{c}{ Variable } & Log Saving & Relative Saving & Absolute Saving \\
\hline Saving & -0.0304 & -1.7838 & $-0.0190^{* *}$ \\
& $(0.0869)$ & $(7.2830)$ & $(0.0081)$ \\
Age $\times$ saving & -0.0003 & -0.0528 & $0.00016^{* * *}$ \\
& $(0.0009)$ & $(0.0737)$ & $(0.00006)$ \\
Male $\times$ saving & $-0.0418^{*}$ & -1.6300 & 0.0001 \\
& $(0.0217)$ & $(1.8317)$ & $(0.0011)$ \\
Married $\times$ saving & 0.0988 & 8.0363 & 0.0093 \\
& $(0.0645)$ & $(5.4886)$ & $(0.0072)$ \\
Single $\times$ saving & 0.0900 & 8.1263 & 0.0095 \\
& $(0.0680)$ & $(5.8291)$ & $(0.0072)$ \\
Widow $\times$ saving & 0.0794 & 7.8955 & 0.0059 \\
& $(0.0655)$ & $(5.5882)$ & $(0.0072)$ \\
Age & 0.0010 & 0.0012 & -0.0012 \\
& $(0.0030)$ & $(0.0023)$ & $(0.0017)$ \\
Male & 0.0734 & 0.0456 & 0.0098 \\
& $(0.0726)$ & $(0.0553)$ & $(0.0414)$ \\
Manried & -0.3411 & -0.2357 & -0.1362 \\
Single & $(0.2195)$ & $(0.1753)$ & $(0.1377)$ \\
& -0.3739 & -0.2949 & -0.1936 \\
Widow & $(0.2289)$ & $(0.1830)$ & $(0.1436)$ \\
& -0.2805 & -0.2261 & -0.1036 \\
Constant & $(0.2217)$ & $(0.1772)$ & $(0.1389)$ \\
& 0.1715 & 0.1272 & 0.2382 \\
& $(0.2931)$ & $(0.2290)$ & $(0.1756)$ \\
\hline
\end{tabular}

Note: "*4." ", and " denote significance at the $1 \% .5 \%$, and $10 \%$ level. respectively.

Each column contains results of a separate regression of the low-tax indicator on one of the tax measures and other variables.

$10 \%$ level. There is, however, no evidence of a difference in the strength of effect between tax decreases and increases. ${ }^{20}$

Finally, in the results reported in table 8, we allow for a different response by demographic groups. Because of the data limitations (see the appendix), the sample used in these analyses includes only the reforms that occurred between 1926 and 1942. There is no evidence for the presence of a differential response by age, gender, or marital status. Although the coefficient on the interaction of tax saving with being a male is significant at the $10 \%$ level for the logarithmic specification (and suggests a weaker response), it is insignificant for the other two specifications. Similarly, the coefficient on the interaction with age is significant only for the absolute specification (at the $1 \%$ level, however). No additional coefficients are significant when we restrict the constant to 0 , and when we include each interaction term separately. (These results are not reported.)

\section{Conclusion}

There is abundant evidence that some people will themselves to survive in order to live through a momentous event. Evidence from estate-tax returns suggests that some people will themselves to survive a bit longer if it will enrich their heirs. To be sure, the evidence is not overwhelming. Nevertheless, our central estimate is that, for individuals dying within two weeks of a tax reform, a

\footnotetext{
${ }^{20}$ In a working-paper version of this paper, we relied on a zero restriction on a constant and found some weak evidence for the presence of such a difference. This result disappeared when we allowed for the seasonal pattern of deaths.
}

$\$ 10,000$ potential tax saving (using 2000 dollars) increases the probability of dying in the lower-tax regime by $1.6 \%$. That there is any effect at all adds to the large body of evidence that taxes affect behavior, and particularly the timing of behavior, including activities such as marriage and childbearing, which are not generally thought to respond to financial incentives.

We cannot rule out that what we have uncovered is not a real death elasticity, but instead ex post doctoring of the reported date of death to save on taxes. Even in that case, this exercise provides evidence on how the attempt to collect taxes can engender resource-using avoidance responses that reduce tax revenue.

\section{REFERENCES}

Alm, James, and Leslie Whittington, "Does the Income Tax Affect Marital Decisions?" National Tax Journal 48:4 (1995), 565-572.

Anson, Ofra, and Jon Anson, "Surviving the Holidays: Gender Differences in Mortality in the Context of Three Moslem Holidays." Sex Roles 37:5-6 (1997), 381-399.

Auerbach, Alan J.. and Joel Slemrod, "The Economic Effects of the Tax Reform Act of 1986." Joumal of Economic Literature 35:2 (1997), 589-632.

Burman, Leonard, Kim Clausing, and John O'Hare, "Tax Reform and Realizations of Capital Gains in 1986," National Tax Journal 47:1 (1994), 1-18.

Burman, Leonard, and William Randolph, "Measuring Permanent Responses to Capital-Gains Changes in Panel Data," American Economic Review 84:4 (1994). 794-809.

Dickert-Conlin, Stacy, and Amitabh Chandra, "Taxes and the Timing of Births," Journal of Political Economy 107:1 (1999), 161-177.

Gelardi, Alexander M. G., "The Influence of Tax Law Changes on the Timing of Marriages: A Two-Country Analysis," National Tax Journal 49:1 (1996), 17-30.

Goolsbee, Austan, "What Happens When You Tax the Rich? Evidence from Executive Compensation," Journal of Political Economy, 108:2 (2000), 352-378.

Hershey, Robert, "Rise in Death Rate after New Year is Tied to the Will to See 2000," The New York Times (January 15, 2000).

Johnson, Barry W., "Estate Tax Returns, 1986-1988," in Barry W. Johnson (Ed.), Compendium of Federal Estate Tax and Personal Wealth Studies, Pub. 1773 (4-94), Department of Treasury, Internal Revenue Service (1994).

Kopczuk, Wojciech, and Joel Slemrod, "The Impact of the Estate Tax on the Wealth Accumulation and Avoidance Behavior of Donors," in William G. Gale, James R. Hines, Jr., and Joel Slemrod (Eds.), Rethinking Estate and Gift Taxation (Washington: Brookings Institution Press, 2001).

Luckey, John R., "A History of Federal Estate, Gift, and GenerationSkipping Taxes," CRS Report for Congress \#95-444A. Congressional Research Service, (Washington: The Library of Congress March 16, 1995)

McCubbin, Janet G. "The Intergenerational Wealth Study: Basic Estate Data, 1916-1945," Statistics of Income Bulletin (Washington: Internal Revenue Service, Spring 1990).

Phillips, David P., and Kenneth A. Feldman, "A Dip in Deaths before Ceremonial Occasions: Some New Relationships between Social Integration and Mortality." American Sociological Review, 38:6 (1973), 678-696.

Phillips, David P., and E. W. King, "Death Takes a Holiday: Mortality Surrounding Major Social Occasions," Lancet 2:8613 (1988), 728732.

Phillips, David P., and D. G. Smith, "Postponement of Death until Symbolically Meaningful Occasions," Journal of the American Medical Association, 263:14 (1990), 1947-1951.

Scholes, Myron, Peter Wilson, and Mark Wolfson, "Firms' Responses to Anticipated Reductions in Tax Rates: The Tax Reform Act of 1986," Journal of Accounting Research, 30:Suppl (1992), 161185. 
DYING TO SAVE TAXES: EVIDENCE FROM ESTATE-TAX RETURNS ON THE DEATH ELASTICITY 265

Table Al.-Chronology op Pre-1945 estate-Tax Blis

\begin{tabular}{|c|c|c|c|c|c|}
\hline $\begin{array}{l}\text { House Bill } \\
\text { Passed }\end{array}$ & $\begin{array}{l}\text { Senate Bill } \\
\text { Passed }\end{array}$ & $\begin{array}{l}\text { Conference } \\
\text { Agreement }\end{array}$ & $\begin{array}{c}\text { Conference } \\
\text { Bill Passed } \\
\text { by House }\end{array}$ & $\begin{array}{l}\text { Conference } \\
\text { Bill Passed } \\
\text { by Senate }\end{array}$ & $\begin{array}{l}\text { Bill Signed by President } \\
\text { and Effective Date }\end{array}$ \\
\hline $\begin{array}{l}2 / 1 / 17 \\
5 / 23 / 17 \\
9 / 20 / 18 \\
2 / 29 / 24 \\
12 / 28 / 25 \\
4 / 1 / 32 \\
2 / 2 / 34 \\
8 / 5 / 35 \\
6 / 11 / 40 \\
8 / 4 / 41 \\
7 / 20 / 42\end{array}$ & $\begin{array}{c}2 / 28 / 17 \\
9 / 10 / 17 \\
12 / 23 / 18 \\
5 / 12 / 24 \\
2 / 13 / 26 \\
6 / 1 / 32 \\
4 / 17 / 34 \\
8 / 16 / 35 \\
6 / 20 / 40 \\
9 / 8 / 41 \\
10 / 10 / 42\end{array}$ & $\begin{array}{c}\text { n.a. } \\
10 / 1 / 17 \\
2 / 6 / 19 \\
5 / 24 / 24 \\
2 / 22 / 26 \\
6 / 3 / 32 \\
4 / 30 / 34 \\
8 / 22 / 35 \\
6 / 21 / 40 \\
9 / 15 / 41 \\
10 / 19 / 42\end{array}$ & $\begin{array}{l}\text { n.a. } \\
10 / 1 / 17 \\
2 / 8 / 19 \\
5 / 26 / 24 \\
2 / 22 / 26 \\
6 / 4 / 32 \\
5 / 1 / 34 \\
8 / 23 / 35 \\
6 / 22 / 40 \\
9 / 16 / 41 \\
10 / 20 / 42\end{array}$ & $\begin{array}{c}\text { n.a. } \\
10 / 2 / 17 \\
2 / 13 / 19 \\
5 / 24 / 24 \\
2 / 25 / 26 \\
6 / 6 / 32 \\
5 / 3 / 34 \\
8 / 23 / 35 \\
6 / 22 / 40 \\
9 / 18 / 41 \\
10 / 20 / 42\end{array}$ & $\begin{array}{c}3 / 31 / 17 \\
10 / 4 / 17 \\
2 / 24 / 19 \\
6 / 2 / 24 \\
2 / 26 / 26 \\
6 / 6 / 32 \\
5 / 10 / 34 \\
8 / 30 / 35 \\
6 / 25 / 40 \\
9 / 20 / 41 \\
10 / 21 / 42\end{array}$ \\
\hline
\end{tabular}

Note: n.a. means that the conference commituce procedure was bypassod.

Schulz, Richard, and Max Bazerman, "Ceremonial Occasions and Mortality: A Second Look," American Psychologist 35:3 (1980), 253261 .

Sjoquist, David L., and Mary Beth Walker, "The Marriage Tax and the Rate and Timing of Marriage," National Tax Joumal 48:4 (1995), 547-558.

Slemrod, Joel, "The Economic Impact of Tax Reform," pp. 1-12 in J. Slemrod (Ed.), Do Taxes Matter? The Impact of the Tax Reform Act of 1986 (Cambridge, MA: The MIT Press, 1990).

U.S. Department of Commerce "Vital Statistics Rates in the United States 1900-1940," Sixteenth Census of the United States (Washington: U.S. Government Printing Office, 1943).

U.S. Department of Commerce, Bureau of the Census, "Vital Statistics of the United States" (Washington: U.S. Government Printing Office. annual issues 1937-1945).

\section{APPENDIX}

For the pre-1945 period (table Al) the value of the taxable estate is not present in the data set. We define it as being equal to the value of net worth (gross estate minus debts and mortgages) before 1918, and as the difference between the value of net worth and charitable bequests for 1918 through 1945 (the deduction for charitable bequests was introduced as of January 1, 1918). This definition ignores credits against the tax, funeral and administrative expenses, payments for the support of the decedent's dependents required by local law, uninsured losses during administration, and deductions for the property previously taxed, because our data do not contain information on them. For the post-1945 period, we use the actual adjusted taxable estate from the tax returns. We apply to the taxable estate the actual tax schedule before and after the tax reform, and define tax saving as the difference between them. The information on the estate-tax structure is obtained from the Internal Revenue Code.

The decedent's marital status is not present in our data set before the 1924 reform. Age is missing for most observations in 1917 and for some other observations. For the sample of observations with known age, we regress it on the time trend and the constant. For this purpose, all 677,329 observations (i.e., not just those close to a tax reform) are used. We impute age for the remaining observations using predicted values from this regression. Age is imputed for less than $10 \%$ of observations, and the results are robust to restricting the sample to individuals with known age.

The Tax Reform Act of 1924 was repealed in 1926, but we investigate this reform nevertheless, because repeal was unlikely to be anticipated when it was enacted.

We used monthly mortality numbers from the U.S. Department of Commerce (1943, 1937-1945) to construct the average daily numbers of deaths for every month between 1916 and 1945 . We assumed that they accurately describe the number of deaths occurring in the middle of the month and interpolated them using a cubic spline. We used the interpolated equation to obtain numbers of deaths occurring two weeks before and two weeks after reforms that imply certain probabilities of dying in the low-tax regime. These probabilities were converted to probit coefficients reported in table 6. 